\title{
IAMJ
}

INTERNATIONAL

AYURVEDIC

MEDICAL JOURNAL

Research Article

ISSN: 2320-5091

Impact Factor: 6.719

\section{PHARMACEUTICAL STANDARDIZATION OF DADRUVIDRAVANA MALAHARA}

\author{
K. Lakshmi Reshma ${ }^{1}$, Ch. Sridurga ${ }^{2}$
}

${ }^{1}$ Final Year PG Scholar, Department of Rasa Shastra and Baishajya Kalpana, S V Ayurvedic College, Tirupathi, Andhra Pradesh, India

${ }^{2}$ Professor \& HOD, Department of Rasa Shastra and Baishajya Kalpana, S.V Ayurvedic College, Tirupati, Andhra Pradesh, India

Corresponding Author: reshmagkollipara@gmail.com

\section{https://doi.org/10.46607/iamj1409112021}

(Published Online: November 2021)

Open Access

(C) International Ayurvedic Medical Journal, India

Article Received: 06/11//2021 - Peer Reviewed: 12/11/2021 - Accepted for Publication: 15/11/2021

\section{Check for updates}

\section{ABSTRACT}

Background: Dadruvidravana Malahara is a unique herbs-mineral formulation elucidated in Rasatarangini under Gandhaka Vijnaniya Taranga for the management of Dadru Kushta and Sikta Taila, Shuddha Gandhaka, Shuddha Tankana, Laksha Churna and Chakramarda Beeja Churna are the ingredients. Aim: To standardize various steps involved in the preparation of Dadruvidravana Malahara. Materials and Methods: All the procedures involved during the preparation of Dadruvidravana Malahara were carried out as perclassical references. Result: The final product was presented in the form of ointment and obtained quantity was $1215 \mathrm{gm}$. Prepared Dadruvidravana Malahara was maroon with a pungent odour. Conclusion: The steps carried out can be considered as standard for the preparation of Dadruvidravana Malahara.

Keywords: Malahara, Dadru Kushta, Rasatarangini.

\section{INTRODUCTION}

The key objective of the pharmaceutical study is to produce a safe, effective and quality drug. Efficacy and safety depend solelyon the quality of the drug. The fun- damental part of Ayurveda lays in pharmaceutical processing. Right from the selection of raw drugs till the final product a drug has to undergo various Samskara like Shodhana, Marana etc. Each procedure brings 
Gunantharadana (qualities) to the drug. Dadruvidravana Malahara is a herbo-mineral formulation described in Rasatarangini under Gandhaka Vijnaniya Taranga for the management of Dadru Kushta ${ }^{(1)}$. Here Acharya explains this formulation cures Dadru Kushta, Sikta Taila, Shuddha Gandhaka, Shuddha Tankana, Laksha Churna and Chakramarda Beeja Churna are ingredients. It is prepared by the Malahara Kalpana (Mardana) method. In the present study, a sincere effort hasbeen put to highlight the significance of pharmaceutical procedures and to standardize the method of preparation of Dadruvidravana Malahara.

\section{AIM AND OBJECTIVES:}

Pharmaceutical standardization of various steps involved in the preparation of Dadruvidravana Malahara.

\section{MATERIALS AND METHODS:}

\section{Pharmaceutical source and place:}

Raw drugs for the preparation of Dadruvidravana Malahara were collected from Anjineya Herbals, Vijayawada and Preparation was carried out in Rasa Shastra and Bhaishajya Kalpana department, SV Ayurvedic College, Tirupathi.

The entire pharmaceutical procedure was carried in different steps:

1. Shodhana of Gandhaka ${ }^{(2)}$

2. Shodhana of Tankana ${ }^{(3)}$

3. Powdering of Laksha and Chakramarda Beeja ${ }^{(4)}$

4. Preparation of Dadruvidravana Malahara.

Procedure:

Initially, Shodhana of Gandhaka was carried out with Goksheera. Milk was taken in a glass vessel. A cloth was tied to its mouth. Ashuddha Gandhaka was taken in a Khalwa Yantra and made into fine powder. GoGhrita was taken in a Lohadarvi and was heated on Mandagni. Fine powder of Ashuddha Gandhaka was added to Lohadarvi and heated till it gets completely melted. Melted Ashuddha Gandhaka was poured into milk through the cloth. Gandhaka was taken out from milk and washed with hot water. The above process is repeated 6 times.

Fresh milk was taken each time. After completion of the process, Shuddha Gandhaka was taken out dried, pounded into a fine powder, weighed and stored in a glass container.

Ashuddha Tankana was taken in a clean and dry Khalwa yantra and pounded into powder. It was taken in an earthen plate and heated on Mandangi. The heat was continued until the water content in the Tankana was completely evaporated. Then it is powdered and stored in an airtight glass container.

Laksha and Chakramarda Beeja were taken, and external impurities were removed. They were pounded separately in Khalwa Yantra and sieved through a cloth and fine powders were obtained.

Sikta was taken in a Khalwa Yantra and pounded into small pieces. Tila Taila was taken in a stainless-steel vessel and heated till bubbles appear. Pounded Sikta was added to hot oil and mixed continuously until Sikta was completely melted in hot oil. Hot Tila Taila was filtered through a cotton cloth, to remove any physical impurities. Filtered Sikta Taila was collected in a vessel.

Hot Sikta Taila was taken in a Khalwa Yantra. Fine powders of Shuddha Gandhaka churna, Shuddha Tankana churna, Laksha churna and Chakramarda Beeja churna were added little by little into Sikta Taila and mixed well. After cooling, the mixture attained semi-solid consistency. This maroon colour mixture is Dadruvidarava Malahara.

Table 1: Ingredients and quantity of Dadruvidarava

\begin{tabular}{|l|l|}
\hline Ingredients & Quantity \\
\hline Sikta Taila & 12 Tola \\
\hline Shuddha Gandhaka & 1 Tola \\
\hline Shuddha Tankana & $1 / 2$ Tola \\
\hline Laksha Churna & $1 / 2$ Tola \\
\hline $\begin{array}{l}\text { Chakramarda Beeja } \\
\text { Churna }\end{array}$ & $1 / 2$ Tola \\
\hline
\end{tabular}

Malahara.

\section{OBSERVATIONS:}

- Gandhaka Shodhana: Melted Gandhaka looked like ghee. On pouring molten Gandhaka through cloth, impurities like small stones, mud, etc were filtered over the cloth. After Shodhana, Gandhaka colour was changed from dull yellow to thick, bright yellow colour with increased lustre. 
GoDugdha and GoGhrita Gandha were observed in Shuddha Gandhaka. Dugdha was hot after Dhalana.

- Tankana Shodhana: Crackling sounds were observed during the process. Tankana, after Shodhana bloomed and turned in to white opaque substance.

- Sikta Taila: On complete melting of Sikta, a homogenous mixture of Sikta and Taila was obtained. On pouring hot Sikta Taila through cloth, impurities like small stones, mud, etc were filtered over the cloth.

- Dadruvidravana Malahara: Maroon coloured Dadruvidravana Malahara was formed.

\section{RESULTS:}

The final product was presented in form of ointment. Organoleptic characteristics and final weight are given in the table below

Table 2: table showing organoleptic characters of Dadruvidravana Malahara

\begin{tabular}{|l|l|}
\hline Colour & maroon colour \\
\hline Odour & Pungent \\
\hline Texture & smooth \\
\hline Final weight & 1215 gms \\
\hline
\end{tabular}

\section{DISCUSSION}

\section{Gandhaka Shodhana:}

Sulphur turns into liquid at $115.21^{\circ} \mathrm{C}$. However, at that temperature, arsenic sulphides (Orpiment Melting Point ${ }^{(5)} \rightarrow 310^{\circ} \mathrm{C}$, Realgar Melting Point ${ }^{(6)} \rightarrow 360^{\circ} \mathrm{C}$ ) which are one of the chief impurities of sulphur stay in ghee as fine small solid particles. These crystals stay back in cloth and liquid sulphur flows freely through fine pores. Repetition of this procedure seven times removes any traces of arsenic.

'Ghee - Milk procedure' can effectively separate sulphur granules from external impurities. Pure sulphur is neither lipid nor water-soluble, therefore, both water and lipid-soluble impurities can be separated from sulphur, as sulphur has to pass through both media.

Ghee serves as a base for the uniform spreading of temperature. It layers fine powder crystals of sulphur and prevents them to get in contact with external oxygen, which otherwise causes oxidation and considerable weight loss.

Nowadays, most of the sulphur we get is extracted as a byproduct of petroleum refining. This type of sulphur will contain some amount of petroleum remnants. They dissolve in lipids as both are non-polar ${ }^{(7)}$ and finally get eliminated from sulphur.

Gandhaka is highly Pitta Vardhaka ${ }^{(8)}$. Both ghee and milk are Vata Pitta Shamaka Dravya ${ }^{(9)}$ and among them, ghee is the drug of choice among fats in reducing Pitta. Therefore, these can reduce 'Teevra Pitta Vruddhikara' effect of Gandhaka.

Milk and Ghee are Vishahara and Rasayana. These can remove Visha Dosha of Gandhaka and impregnate Rasayana property to Gandhaka.

Calcium present in milk acts as a reducing agent which helps in the removal of impurities. Calcium also acts as chelating agent during detoxification.

Final cleaning with hot water removes greasy remnants of milk and ghee.

\section{Tankana Shodhana:}

After Shodhana $\mathbf{N a}_{2} \mathbf{B}_{4} \mathbf{O}_{7} \mathbf{1 0} \mathbf{1 0 H}_{2} \mathbf{O}$ converted into $\mathrm{Na}_{2} \mathrm{~B}_{4} \mathrm{O}_{7} . \mathbf{5 H}_{2} \mathrm{O}$ due to the evaporation of water molecules during heating.

Purified Tankana contains more Boron (13.48\%) compared to raw Tankana (10.08\%).

\section{Sikta Taila Nirmana:}

The base of the drug Dadruvidravana Malahara is Sikta Taila. Sikta Taila has emollient property. The Taila hydrates and softens the skin. It prevents the escape of water through the skin by forming a protective layer above the lesion.

Hydration of skin increases absorption of the drug. Thus, Sikta Taila might be the ideal base for the preparation of Malahara.

When Bee's wax is combined with borax it exhibits, emulsifying property thereby increasing the binding capacity among the ingredients of the drug ${ }^{(10)}$.

Dadruvidravana Malahara Preparation: Dadruvidravana Malahara was prepared as per the reference of Rasatarangini. It was prepared by following the general method of Malahara Kalpana and presented in the form of ointment. The prepared Sikta Taila was 
taken in a Khalwa Yantra, to that Shuddha Gandhaka Churna, Shuddha Tankana Churna, Laksha Churna and Chakramarda Beeja Churna were taken one after the other and Mardana was done till a homogenous mixture which has butter-like consistency was formed. This mixture is Dadruvidravana Malahara. Organoleptic characterswere observed and stored in air-tight glass containers.

\section{CONCLUSION}

Pharmaceutical standardization helps in developing standard manufacturing procedures without disturbing the efficacy and safety profile of the drug. The pharmaceutical procedure involved here was Shodhana, Dhalana, Nirjalikarana, Churna Nirmana and Mardana. The procedure of Shodhana removes the toxins in Gandhaka and reduction of its compactness. Shodhana of Tankana removes its Gurutvam. Churna Nirmana and Vastragalitam procedure helps in size reduction and makes the drug more bioavailable. Sikta Taila acts as a binding agent and also gives proper consistency to the Malahara. This helps in the easy application of the Malahara.

\section{REFERENCES}

1. Kashinath Shastrina, Rasa Tarangini by Motilal Varanasi Das Prakashana, Reprint 2014, Chapter8/59-62. Pg. No. 87.
2. Siddhi Nandana Mishra, Rasa Ratna Samuchchayah by Chaukhambha Orientalia, reprint2017, Chapter 3/20-22. Pg.No. 64.

3. Kashinath Shastrina, Rasa Tarangini by Motilal Varanasi Das Prakashana, Reprint 2014, Chapter 13/77-78, Pg. No 315

4. Dr P. Himasagar Chandra Murthy, Sharangadhara Samhita by Chowkhambha Sanskrit Series Office, Edition 2010, Madhyama Khanda Chapter 6/12, Pg.No. 154

5. http://en.wikipedia.org/wiki/Arsenic_trisulfide

6. http://www.chemicalbook.com/ChemicalProductProperty_EN_CB4367754.htm

7. http://www.rpi.edu/dept/bcbp/molbiochem/MBWeb/mb1/part2/lipid.htm

8. Shri Gulraja Sharma, Ayurveda Prakasha by Chaukambha Bharati AcademyReprint 2016, Chapter 2/116. Pg.No.260.

9. G.S. Pandey, Shivaprakash Nighantu by Chaukambha Bharati Academy, Dugdhavarga Sloka No.8, Pg.No. 742.

10. https://formulabotanica.com/beeswax-is-not-an-emulsifier/

\section{Source of Support: Nil Conflict of Interest: None Declared}

How to cite this URL: K Lakshmi Reshma: Pharmaceutical Standardization Of Dadruvidravana Malaharak. International Ayurvedic Medical Journal \{online\} 2021 \{cited November 2021\} Available from: http://www.iamj.in/posts/images/upload/2736_2739.pdf 